authors however, do not discuss the problems associated with such modern adaptations of medieval texts and do not explain the principles that were adopted during the adaptations. Also, it is a pity that the translated sources do not include material from medieval Livonia which is surprising given that records from $15^{\text {th }}$ century inspections of Teutonic castles in Livonia were already published by Polish scholars. ${ }^{1}$ Most often, translations are based on $19^{\text {th }}$ century publications, not on the original manuscripts although this is understandable. A more serious prob$\mathrm{lem} /$ issue is the fact that it is not always clear who the author of the presented translations is. Sometimes the author is provided in a footnote but this is not always the case. Similarly, it is not always clear who is the author or what is the source of the presented photographs, plans and reconstructions.

Despite these minor limitations, the discussed volume represents a valuable initiative that will prove valuable to both educated wider audience and scholars specialising in the medieval history of the Baltic region. In the opinion of the reviewer, its principal advantage is the broad spectrum of its collected studies which allows for extensive comparisons between Teutonic Prussia and Livonia which is surprisingly rare in the modern literature. The only significant omission is the absence of articles that would focus on art and the theme of religiosity which certainly played important roles in both Prussia and Livonia though perhaps the addition of such studies would make the volume too long and more difficult to navigate through.

Tomasz Borowski (Reading)

\title{
Crusading and Chronicle Writing on the Medieval Baltic Frontier. A Com- panion to the Chronicle of Henry of Livonia, eds. Marek Tamm, Linda Kaljundi, Carsten Selch Jensen, Ashgate Publishing Company, Farnham 2011, 487 pp. + illustrations and maps, ISBN 978-0-7546-6627-1.
}

The Cronicon Lyvoniae by Henry of Livonia has been a subject of intensive, interdisciplinary studies for over 150 years. The academic interest in this four volume long chronicle, covering the history of Livonia from 1180-1227, and in its author, has additionally intensified after the collapse of the USSR and the regaining of the independence of the Baltic States, particularly Latvia and Estonia as their borders follow the historical boundaries of medieval Livonia. As a result, at the end of the

1 M. Biskup, Wizytacja zamków zakonu krzyżackiego w Inflantach z 1488 roku, Zapiski Historyczne 49 (1984), 1, pp. 119-128. 
last decade, a group of Estonian and Danish medievalists have synthesized the past research on the chronicle and published the results of their study in the volume discussed here. The publication is the outcome of the conference Crusading and Chronicle Writing on the Medieval Baltic Frontier: The Chronicle of Henry of Livonia organised by the Centre for Medieval Studies at Tallinn University, the Nordic Centre for Medieval Studies and the Department of Church History at Copenhagen University, which took place in Tallinn on 22-24 May 2008.

The articles included in the volume are divided into three sections: "Representations", "Practices" and "Appropriations". The preface written by James A. Brundage, who is an experienced researcher on the crusades and the translator of the source into English, provides an introduction to studies of Henry of Livonia and his chronicle. The author indicates that the main obstacle in the research of the chronicle and its author is that all information about him and his work comes from the chronicle itself. Brundage outlines the biography of Henry of Livonia indicating his origin and relation to the congregation of the Canons Regular of the Lateran in Segeberg, which shaped him both spiritually and intellectually. The author also considers the question whether Henry of Livonia participated in the Christianisation of Livonia and sets the discussion within a wider framework of the contemporary Canon Law and its view on the involvement of the Latin clergy in the struggles against the local population in the Baltic region.

The first part of the volume, entitled "Representations", collects articles addressing different ideas and messages conveyed in the chronicle by the author and the way in which they are presented. The section starts with the study by Christopher Tyerman concerning the use of crusader ideology in Henry's chronicle. The text makes references to other historiographical narratives describing crusades in different regions such as the chronicle by William of Tyre. The second article, by Jaan Undusk, discusses the sources of inspiration and appropriations in Henry of Livonia's work. The study emphasizes the priority of the Vulgate and the breviary. The identified borrowings include references to Latin texts from the scholastic canon of the time, citations of the Fathers of the Church, extracts from contemporary documents and borrowings from the language of the local pagan population. The third study, by Jüri Kivimäe, uses the way in which Henry of Livonia presented himself in the chronicle, as a basis for investigating the way in which he described the various Baltic and Finno-Ugric peoples inhabiting the region such as the Livovians, the Aesti or the Latgalians. Kivimäe's findings are complemented by the following study by Torben Kjersgard Nielsen who uses the research by Jacques Le Goff and French structuralists such as C. Lévi-Strauss, as the starting point for analysing the way in which Henry describes the natural environment, focusing on forests and their significance for the local population (refugium, sacral func- 
tions, etc.). Henry of Livonia presents himself as a parish priest, the chaplain of the bishop of Riga Albert (1199-1229) and interpreter (interpres). Alan V. Murray devotes his study to Henry of Livonia's role as an interpreter, pointing out other meanings of the term interpres (the one who explains), which for him is a starting point for the analysis of the linguistic aspects of the mission in Livonia on the basis of the chronicle. Murray examines not only the linguistic skills of the chronicler, but also the organization of the church on the territory of the mission in Livonia and its relation to local linguistic barriers. The analysis is complemented by the study by Casten Selch Jensen who focuses on sermons as a prevailing form of transmitting ideological messages in the medieval period. The article discusses the rhetoric tools used in the sermons recorded in the chronicle as well as the clergymen who have delivered the homilies.

The studies collected in the second part of the volume, entitled "Practices", demonstrate the immense significance of the chronicle by Henry of Livonia as a source used in the analysis of various aspects of the medieval history of Livonia. In the opening article, the Danish medievalist Iben Fonnesberg-Schmidt discusses the relationship between the newly-created church in Livonia and the Papacy. The starting point for this analysis is the excerpt of the chronicle describing how Bishop Albert of Riga attempted to gain support for the Christianisation in Livonia at the Roman curia. The subject is particularly important as Papal letters played crucial role in the recruitment of crusaders and the authorisation of crusades in Livonia. Articles by Kurt Villads Jensen and Ain Mäesalu focus to the military aspects of the events described in the chronicle. As a witness of crusader warfare against the pagans, Henry of Livonia included a great deal of information about the manner in which military actions were conducted in the Baltic at the beginning of the $13^{\text {th }}$ century. The chronicle describes not only the weapons that were used but also popular tactics. According to Mäesalu, Henry of Livonia possessed great knowledge in that area, particularly when using terms referring to long-range weapons (crossbows, ballistae), stone-hurling devices (catapults), ammunition (iaculum, telum) and the crew operating the weapons (ballistarii). He analyses the use of the weapons in defensive actions, near rivers or lakes and during sieges. The study refers to numerous archeological findings, and provides detailed discussion of the range of weapons that were adopted and used by the pagans (mainly by the Aesti). In the next article, Valter Lang and Heiki Valk analyse to what extent archaeology can be used to verify the information derived from Henry's chronicle. The authors observe that occasionally, archaeological finds from sites associated with military campaigns can confirm the narrative recorded by Henry. They also demonstrate how archaeology can be used to provide a broader picture complementing the written sources which, by their nature are often fragmentary. The following article, 
by Marika Mägi also refers to archeological research. She examines the negative picture of Osel and its inhabitants presented by Henry of Livonia according to whom, the inhabitants of the island were badly organized, their community lacked central management and derived its profit from plundering raids. The evidence presented by Mägi suggests a very different image, according to her findings, the inhabitants of Osel constituted a well organised community that was aware of the political events around it and made unsuccessful attempts to negotiate with the king of Denmark. The criticism of Oselians by Henry of Livonia therefore is said to have been politically motivated.

The last part of the volume, entitled "Appropriations", consists of texts discussing questions concerning the reception of the chronicle and its influence on historiography from the Middle Ages to modern times. Anti Selart, referring to the research by Leonid Arbusow Junior, stresses the existence of a medieval copy of the chronicle from the $13^{\text {th }}$ century that is deposited as Codex Zamoscianus in the National Library in Warsaw. It is shown that political changes in Livonia had significant effect on the reception of the image of Livonia presented in the text; in the mid- $13^{\text {th }}$ century for example its importance was viewed mainly from the perspective of the rivalry between the Teutonic Order and archbishops of Riga. Interest in the chronicle of Henry of Livonia grew in the early modern period when it was published in 1740 by Johann Daniel Gruber. Stefan Donecker follows the history of the preserved manuscripts of the chronicle and focuses on its oldest copies together with notes left on their margins by later scholars (Codex Zamosciansus, Codex Oxenstierna, Hanoveranus) to discuss the interest that they provoked in the early modern period in Germany and Livonia. Similar issues are discussed by Tiina Kala in her article describing the preserved manuscripts of the chronicle and analysing their various editions and translations from the previously mentioned publication by Gruber from 1740 to the Finnish translation by Maijastina Kahlos and Raija Sarasti-Wilenius from 2003. The volume finishes with the text written by Linda Kaljundi about the significance and role of Henry of Livonia and his chronicle for the history of the Baltic States and the formation of their national identities from the Enlightenment to modern period.

The discussed volume is a valuable publication to any researcher dealing with the medieval history of the eastern Baltic. It provides a synthesis of the past, interdisciplinary research on one of the most fundamental sources for the history of the region. The book sums up the achievements of national historiographies and is undoubtedly an excellent commentary to the past editions and translations of the chronicle by Henry of Livonia. 